\title{
Foucault e a crítica da verdade
}

CANDIOTTO, Cesar. Foucault e a crítica da verdade. Belo Horizonte: Autêntica; Curitiba: Champagnat, 2010.

\section{Fred Mendes Stapazzoli Junior}

Mestre em Filosofia pela Pontifícia Universidade Católica do Paraná (PUCPR), Florianópolis, SC - Brasil, e-mail: stapazzoli@gmail.com

E tentou nos advertir o autor, Cesar Candiotto, nas páginas finais de seu Foucault e a crítica da verdade:

[...] o trabalho intelectual de Michel Foucault é indissociável de suas práticas, de seus engajamentos nas lutas locais, de sua crítica às tecnologias institucionais postas em funcionamento no mundo ocidental, de sua aversão às morais de estado-civil e assim por diante. A esse respeito, o presente trabalho prescindiu da biografia do filósofo, embora se saiba que suas práticas nutriam suas formulações teóricas e vice-versa. Seja ressaltado, contudo, que a única coerência que ele reivindica para si próprio é a coerência de sua vida. Jamais Foucault procurou se identificar com as lutas das quais participou, dos movimentos que apoiou, pois temia ser localizado pelas identificações do poder (CANDIOTTO, 2010, p. 167, grifo nosso).

Há mais explícita grafia de um bíos nessas linhas que se leem? Tal qual o poder nesse autor - uma ficção, uma abstração entre no mínimo dois que resistem, passível de apreensão em seus efeitos germinais -, eis uma versão da biografia, e neste momento não nos preocupamos com o sentido que talvez o beletrista empreste a esse último termo. Do 
contrário, parece-nos que o trabalho de Candiotto não prescinde dessa relação inextricável entre vida e obra que aos leitores de Foucault tomam relevo em todo instante de retorno ao texto desse pensador - pelo menos aqueles que se suspendem do "lugar comum" (CANDIOTTO, 2010, p. 15).

Na leitura de cada linha dessa versão da crítica da verdade, algo da ordem do inapreensível se extrai. É como um corpo que desaparece e na sua ausência resiste e permanece vivo; um traço presente, uma marca; um registro indelével. É como o fim do romance. Quem já o viveu algum dia conhece a espécie de vão combate que travamos naquele momento em que se tenta apagar tudo e de uma só vez. Que tentativa inócua! É como se aquilo que não é mais, entretanto sendo vivo, transbordasse. Há um resto que escorre de toda versão, de toda ficção, de toda fantasia que nos aproxima e nos declara, ao mesmo tempo, separados desde sempre - separados como o temor do filósofo francês em relação às localizações precisas e identificações.

No empreendimento teórico de Candiotto, Foucault e a crítica da verdade, da primeira letra ao seu ponto último, outra coisa não fazemos, nós leitores, senão juntar, como o próprio autor o fez, as sobras do que restou desse algo a que chamamos Foucault: traços, marcas, registros que se extravasam das linhas que se escreveram. Pelo menos a nós isto é o que fica. A nós esse é o "perigo principal" eleito, que, em cascata, ameaça e exige um posicionamento (CANDIOTTO, 2010, p. 168). A nós isso se desenha nessas impressões de leitura.

Foucault, de suas perspectivas de análise - sempre nuançadas e revistas ao longo de sua trajetória intelectual -, posicionou-se em face dos perigos que, diga-se de passagem, tomam a forma do iminente xeque-mate. Fatal, por certo. Candiotto, de sua parte, também pinçou um perigo e não muito longe dos escritos sobre o qual se debruça, como em um "elogio à diferença", também trafega sobre o fio da navalha. E não poderia ser diferente.

Como depreendemos já de saída, ao aparelhar-se do impensado, arrisca-se o autor da obra em um gesto e, a partir de uma torção do olhar, traça as linhas de sua aposta: “[...] analisar a possibilidade de uma história crítica da verdade articulada em torno da constituição 
do sujeito, como fio condutor da investigação de Michel Foucault" (CANDIOTTO, 2010, p. 20, grifo do autor).

Atentemos ao destaque: uma história. Sim, uma história que corre quase que em suspenso nessa História legitimada por práticas discursivas e não discursivas. E por que não pensarmos em uma história que Candiotto, a partir de cortes, disjunções e aproximações daquilo que restou, entrevê algo que afirma ter prescindido, mas que brota sob o olhar do leitor? Isso foi por ele criado, por certo, muito embora na mesma medida em que nos aproximemos desse entre em igual proporção nos escape. Há uma diferença aí registrada, coisa que pode ser aproximada ao deslocamento e à torção do olhar. Daí o resultado: a ficção de Candiotto, que, atento, "ficcionou" o indiscernível entre verdade, ação e vida, bem ao gosto de Foucault, recriando-o - justamente aquilo que transborda, que sobra; a marca indelével de sua obra, uma história crítica da verdade.

Não sem desespero, diante de todo o horror de sentir o chão desabar sob os nossos pés, outras ficções imaginárias (e imaginárias porque seguras e totalizadoras) são excluídas dessa versão - uma, dentre tantas outras. Mas nem por isso e ao mesmo tempo podemos, maravilhados, deixar de assistir ao espetáculo trágico dessa leitura em que algo cai e dali mesmo emerge. Por um lado, essas grandes verdades forjadas na e pela História - isso que fantasticamente nos agarramos ou, dito noutros termos, fixam identidades, fixam modos de ser e de agir caem; por outro, das ruínas, alguma possibilidade. Candiotto a entreviu e a registrou em sua obra. Dentre os excertos que cita, um possível e excelso fim da tragédia, dentre os quais talvez cheguemos, da lavra de Michel Foucault:

dou-me conta que não escrevi nada além de ficções. Não quero dizer, porém, que isso esteja fora da verdade. Parece-me que é possível fazer trabalhar a ficção na verdade, induzir efeitos de verdade com um discurso de ficção, e fazer de algum modo que o discurso de verdade suscite, fabrique algo que não existe ainda, portanto, que ele "ficcione". "Ficcionamos" a história a partir de uma realidade política que a torna verdadeira, "ficcionamos" uma política que não existe ainda a partir de uma verdade histórica (FOUCAULT, 1994 apud CANDIOTTO, 2010, p. 165, grifo nosso). 
Se falamos em tragédia, já que muito além da obra é uma vida que se coloca em jogo, entre a miséria e o sublime, entre a vida e a morte, talvez um refúgio: a partir de Foucault podemos pensar que referidas ficções constituam um combate no qual entramos, sem retorno nem saída, restando-nos apenas a coragem de nos lançarmos sobre algo que ainda não existe, mas que possa ter efeito de verdade, caso tenhamos apreendido a confusão entre o escrito e o vivido. Essa é a relação indissociável que não se cala, de ponta a ponta, na aposta efetuada por Candiotto.

Essa impressão de leitura também obrigou-nos a eleger um perigo: não apagar as marcas que o próprio exercício filosófico inscreve nessas biografias e vice-versa.

Recebido: 14/06/2011

Received: 06/14/2011

Aprovado: 20/07/2011

Approved: 07/20/2011 